\section{Basic and Applied Ecology}

www.elsevier.de/baae

\title{
Does the strength of facilitation by nurse shrubs depend on grazing resistance of tree saplings?
}

\author{
Charlotte Vandenberghe ${ }^{\mathrm{a}, \mathrm{b}}$, Christian Smit ${ }^{\mathrm{c}, *}$, Mandy Pohl ${ }^{\mathrm{a}, 1}$, Alexandre Buttler ${ }^{\mathrm{a}, \mathrm{b}}$, \\ François Freléchoux ${ }^{\mathrm{a}, \mathrm{b}}$ \\ ${ }^{a}$ Swiss Federal Research Institute WSL, Station 2, 1015 Lausanne, Switzerland \\ ${ }^{\mathrm{b}}$ Laboratory of Ecological Systems ECOS, Ecole Polytechnique Fédérale de Lausanne EPFL, Station 2, \\ 1015 Lausanne, Switzerland \\ ${ }^{\mathrm{c}}$ Department of Biology, Unit of Ecology \& Evolution, University of Fribourg, Chemin du Musée 10, 1700 Fribourg, Switzerland
}

Received 6 March 2008; accepted 19 August 2008

\begin{abstract}
Facilitation of tree regeneration by nurse shrubs that offer protection against large herbivores is an important driver of wood-pasture dynamics. Here we asked whether the response to facilitation by nurse shrubs depends on the grazing resistance of the protégé saplings. We experimentally tested the protective effects of the thorny Rosa rubiginosa on browsing frequency, survival, and biomass change of saplings of two species-groups, presumably differing in grazing resistance: the coniferous Abies alba and Picea abies and the deciduous Acer pseudoplatanus and Fagus sylvatica saplings. The saplings were planted under and outside $(1.5 \mathrm{~m})$ planted nurse shrubs, under zero, low and high grazing intensity. In total, 1920 young saplings were transplanted to 60 blocks and followed for 1 year.

Although the number of saplings browsed did not differ between species-groups, the coniferous saplings showed lower resistance to cattle browsing (i.e. lower survival and growth rates) than the deciduous saplings. The less resistant coniferous saplings benefited significantly more from nurse shrubs than the more resistant deciduous species in terms of growth of the surviving saplings, but not in terms of overall survival. This was likely due to herbivory on the nurse shrubs causing incidental browsing on protégé saplings and differences in biomass off-take. At high grazing intensity facilitative effects of the nurse shrubs decreased, especially for the coniferous species.

These results have important management implications for the endangered wood-pastures in Western Europe. For a sustainable management and conservation that allows tree recruitment, grazing intensity should remain low to best promote facilitation processes for all tree species, but in particular for the less resistant conifer saplings.

(C) 2008 Published by Elsevier GmbH on behalf of Gesellschaft für Ökologie.
\end{abstract}

\section{Zusammenfassung}

Die Förderung der Baumregeneration durch Ammengebüsche, die einen Schutz gegen große Herbivoren bieten, ist eine wichtige treibende Kraft für die Dynamik von Waldweiden. An dieser Stelle fragten wir uns, ob die Reaktion auf

\footnotetext{
*Corresponding author. Current address: Copernicus Institute for Sustainable Development and Innovation, Environmental Sciences Group, Utrecht University, P.O. Box 80115, 3508 TC Utrecht, the Netherlands. Tel.: + 31302535898 ; fax: + 31302532746.

E-mail addresses: smitchr@gmail.com, c.smit@rug.nl (C. Smit).

${ }^{1}$ Present address: Swiss Federal Research Institute WSL, Unit Ecosystem Boundaries, Alpine Ecosystems, Flüelastr. 11, 7260 Davos Dorf, Switzerland.
} 
die Förderung durch Ammengebüsch von der Beweidungsresistenz der geschützten Schösslinge abhängt. Wir untersuchten den schützenden Effekt der dornigen Rosa rubiginosa auf die Beweidungsfrequenz, die Überlebensrate und die Veränderungen in der Biomasse für Schösslinge aus zwei Artengruppen experimentell, von denen wir annehmen, dass sie sich in der Beweidungsresistenz unterscheiden: die Nadelbäume Abies alba und Picea abies und die Laubbäume Acer pseudoplatanus und Fagus sylvatica. Die Schösslinge wurden unter die und außerhalb $(1,5 \mathrm{~m})$ der gepflanzten Ammengebüsche bei fehlender Beweidung, geringer und hoher Beweidungsintensität gepflanzt. Insgesamt wurden 1920 junge Schösslinge in 60 Blöcken verpflanzt und über ein Jahr beobachtet. Obwohl sich die Anzahl der beweideten Schösslinge nicht zwischen den Artengruppen unterschied, zeigten die Nadelbaumschösslinge eine geringere Resistenz gegenüber der Rinderbeweidung (d. h. geringere Überlebens- und Wachstumsraten) als die Laubbaumschösslinge. Die weniger resistenten Nadelbaumschösslinge profitierten signifikant mehr von den Ammengebüschen als die resistenteren Laubbaumschösslinge in Bezug auf das Wachstum der überlebenden Schösslinge, aber nicht in Bezug auf die Überlebensrate. Dies war wahrscheinlich auf die Beweidung der Ammengebüsche zurückzuführen, bei der zufällig die geschützten Schösslinge mit beweidet wurden, und auf die unterschiedliche Wegnahme von Biomasse. Bei hohen Beweidungsintensitäten nahmen die fördernden Effekte der Ammengebüsche insbesondere für die Nadelbäume ab. Diese Ergebnisse haben wichtige Schlussfolgerungen für die gefährdeten Waldweiden in Westeuropa. Für ein nachhaltiges Management und einen Schutz, der ein Nachwachsen der Bäume ermöglicht, sollte die Beweidungsintensität niedrig bleiben, um den besten Förderungsprozess zu für alle Baumarten zu erlauben, insbesondere für die weniger resistenten Nadelbaumschösslinge.

(C) 2008 Published by Elsevier GmbH on behalf of Gesellschaft für Ökologie.

Keywords: Associational resistance; Biotic interactions; Cattle browsing; Coniferous; Deciduous; Indirect facilitation; Woodpastures

\section{Introduction}

The importance of facilitation for determining ecosystem functioning and dynamics, plant community structure, and regulating biodiversity is now widely acknowledged (Brooker et al., 2008; Bruno, Stachowicz, \& Bertness, 2003; Callaway, Kikodze, Chiboshvili, \& Khetsuriani, 2005; Cheng, Wang, Chen, \& Wei, 2006; Tirado \& Pugnaire, 2005). Facilitative interactions between plants occur when one plant ("nurse plant") modifies, directly or indirectly, the abiotic or biotic environment and consequently increases the performance of a nearby plant ("target plant") (Bertness \& Callaway, 1994; Brooker \& Callaghan, 1998). Facilitative and competitive interactions generally act simultaneously upon neighbouring plants, and recent studies have focussed on how this balance of plant-plant interactions changes along gradients of environmental severity, including abiotic stress or biotic disturbance (sensu Brooker \& Callaghan, 1998; Grime, 1977). In general, the role of facilitation increases with abiotic stress whereas competition decreases (Callaway et al., 2002; Cheng et al., 2006; Choler, Michalet, \& Callaway, 2001; Liancourt, Callaway, \& Michalet, 2005). However, this relationship is not always linear and is currently being vigorously debated (Maestre, Valladares, \& Reynolds, 2006; Michalet et al., 2006; Travis, Brooker, Clark, \& Dytham, 2006). Besides abiotic factors, biotic disturbances such as grazing also influence plant interactions. In ecosystems driven by large herbivores, unattractive, toxic or thorny plants were found to have positive indirect (i.e. grazer mediated) effects on palatable herbs, shrubs or trees (Bakker et al., 2004; Callaway et al., 2005; Smit, Béguin, Buttler, \& Mueller-Schaerer, 2005; Smit, den Ouden, \& Müller-Schärer, 2006). Brooker, Scott, Palmer, and Swaine (2006) and Smit, Vandenberghe, den Ouden, and \& Müller-Schärer (2007) found a hump-backed relationship between facilitation of saplings by a nurse plant and the level of grazing disturbance. The reduced facilitation for saplings under high grazing intensities was related to high net search effort by the herbivores and increased damage to nurse plants. It is known that the strength of facilitation along abiotic stress gradients can differ between target species due to differences in their tolerance to a particular abiotic stress (e.g. shade and moisture) and/or competitive ability (Gómez-Aparicio, Valladares, Zamora, \& Quero, 2005; Liancourt et al., 2005). However, responses of facilitation processes to a biotic disturbance gradient, such as a grazing intensity, have thus far been rarely studied for species that differ in their grazing resistance.

Wood-pastures are ecosystems in which large herbivores drive vegetation dynamics through the maintenance of complex assemblages of grassland, shrub and woodland patches (Bakker et al., 2004; Olff et al., 1999; Vera, Bakker, \& Olff, 2006). Due to their structural heterogeneity, wood-pastures harbour a great biodiversity, including many rare and endangered plant and animal species (Kirby, Thomas, Key, McLean, \& Hodgetts, 1995; Pott \& Hüppe, 1991). They also have a high cultural, socio-economic and landscape value 
(Etienne, 1996). Most ancient wood-pastures are found in places with a long history of extensive livestock grazing and forest management. However, due to current changes in agricultural practices (Etienne, 1996), only a few remnants of this rich system remain scattered across Europe, e.g. Jura Mountains $(\mathrm{CH})$, New Forest (UK), Borkener Paradies (DE), Junner Koeland (NL). Worldwide, there is interest in combining agriculture and siliviculture to conserve and re-establish these endangered systems (Lehmkuhler et al., 2003; Manning, Fischer, \& Lindenmayer, 2006). This requires the maintenance of large herbivore densities which are neither too high to allow shrubs or trees to regenerate nor too low for grassland to regenerate (Gillet, 2005; Kirby et al., 1995; Vera et al., 2006).

Facilitation from nurse plants (e.g. the thorny shrub Rosa rubiginosa L.) is an important process for natural tree establishment in wood-pastures as tree saplings frequently die due to cattle activity (Smit et al., 2006), particularly when grazing intensity is high (Vandenberghe, Freléchoux, Moravie, Gadallah, \& Buttler, 2007). The probability of a sapling being browsed and killed as a result depends on grazing intensity (Hester, Mitchell, \& Kirby, 1996) and browsing resistance of the species (Hester, Bergman, Iason, \& Moen, 2006). Resistance includes appearance (e.g. size or structure), mechanical or chemical defences (e.g. stiff needles, secondary compounds) and specific intrinsic abilities (i.e. tolerance) to survive and regrow after biomass loss under different environmental conditions (Boege \& Marquis, 2005; Rosenthal \& Kotanen, 1994). In the remaining wood-pastures of the Swiss Jura Mountains, two coniferous (Abies alba Miller and Picea abies L.) and two deciduous (Acer pseudoplatanus L. and Fagus sylvatica L., Karst) tree species co-occur naturally. Saplings of coniferous trees appear affected more severely in their growth and survival by cattle browsing than saplings of deciduous trees (Smit et al., 2007; Vandenberghe et al., 2007). The differences in consumption of these tree saplings tend to decrease with grazing intensity most likely as a result of decreased selectivity (Crawley, 1983; Vandenberghe et al., 2007). Hence, the hump-backed curve between the level of grazing disturbance and facilitation strength is expected to be higher for less resistant species, especially at low disturbance. We hypothesized that the benefits of facilitation will be stronger for the less resistant coniferous species and that such benefits will change in a group-specific manner as a consequence of changes in grazing intensity. We therefore experimentally tested the group-specific relationships between a facilitative nurse shrub and the aforementioned coniferous and deciduous tree species under varying grazing intensities. Saplings were planted under and outside the canopy of $R$. rubiginosa in paddocks with three levels of grazing intensity: zero, low and high. The following question was addressed: do coniferous trees benefit more from facilitation by a nurse shrub than deciduous trees (in terms of browsing frequency, survival and growth), under both low and high grazing intensities?

\section{Methods and materials}

\section{Study area}

The experiment was conducted from April 2004 until May 2005 in the Swiss Jura Mountains, at 'La Petite Ronde' (Les Verrières, $6^{\circ} 27^{\prime} 35^{\prime \prime} \mathrm{E}, 46^{\circ} 56^{\prime} 18^{\prime \prime} \mathrm{N}$, altitude $1125 \mathrm{~m}$ a.s.1.). The climate is cold and wet, with a yearly mean temperature of $6.7^{\circ} \mathrm{C}( \pm 1.67)$ and yearly mean precipitation of $1646 \mathrm{~mm}( \pm 424)$, of which $20 \%$ falls as snow (mean \pm 1 SD over 1991-2003). Mean monthly temperature and total precipitation during the grazing season (May-September) of 2004 was $12.1^{\circ} \mathrm{C}( \pm 4.6)$ and $673 \mathrm{~mm}$, respectively.

The vegetation is dominated by grasses (76\%), mainly by Agrostis capillaris L. and Festuca rubra agg. L. The soils are on Argovian marls (Mühlethaler, 1930), rich in clay $(30 \%)$, acidic $(5.5<\mathrm{pH}<6.0)$, locally hydromorphic, and belong to the brown-soil class. No fertilizers have been applied since 1986. The mean productivity of the area for 2004 was $389.4 \mathrm{~g} \mathrm{~m}^{-2}$.

The study area contains three sites and each site consists of two adjacent paddocks. Each year, the paddocks of each site are simultaneously grazed by cattle between May and October following a rotational grazing system with four grazing periods per year. Different grazing intensities are achieved by varying the size of the paddocks, while maintaining a stable herd size of twenty-four 2-year-old heifers.

\section{Experimental design}

Each of the three sites contained a large (6.9-8.2 ha) and small (3.5-4.1 ha) paddock, representing, respectively, low (83.6-106.1 LU (i.e. Livestock Units) days $\mathrm{ha}^{-1}$ ) and high (181.7-204.1 LU days ha ${ }^{-1}$ ) grazing intensities (Fig. 1). We fenced an exclosure (i.e. zero grazing intensity) of $10 \mathrm{~m} \times 60 \mathrm{~m}$ at the border of each paddock. Sward heights (mean \pm 1 SE) measured before and after four rotations correlated well with grazing intensities (low $=56.7 \pm 6.4 \mathrm{~mm}$ and high $=90.1 \pm 10.7 \mathrm{~mm}$ ) (see Smit et al., 2007 for more details). In April 2004, five blocks of $10 \mathrm{~m} \times 10 \mathrm{~m}$ were evenly distributed in each of the 6 paddocks and the zero grazing intensity exclosures (Fig. 1). In each block, we planted four multi-stemmed $R$. rubiginosa of $1.5 \mathrm{~m}$ in height as thorny nurse shrubs at a distance of $7 \mathrm{~m}$ from each other. One shrub each was selected as a nurse plant for one of the four tree species (coniferous: $A$. alba and P. abies; 
deciduous: A. pseudoplatanus and $F$. sylvatica). Eight saplings were planted at each shrub: four saplings were planted near the shrub, i.e. at $<0.1 \mathrm{~m}$ from the stem of the shrub (position "in") and four saplings were planted at $1.5 \mathrm{~m}$ (position "out") from the shrub, all according to the cardinal directions (N, E, S, W). In total, 1920 young saplings were transplanted to the 60 blocks. Saplings were

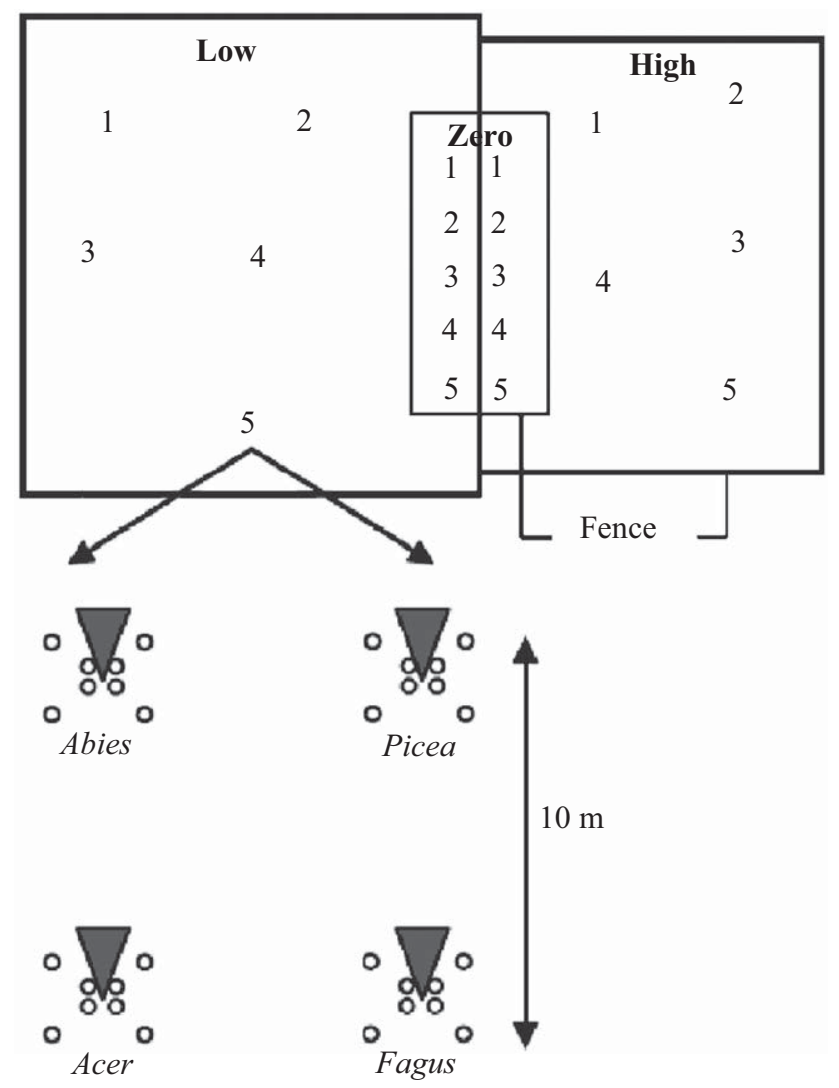

Fig. 1. Experimental design: one of the three sites, consisting of two adjacent paddocks of varying size (low and high grazing intensity) and their exclosure (zero grazing intensity). Five blocks (represented by numbers) were evenly located in each paddock and exclosure. Each block $(10 \mathrm{~m} \times 10 \mathrm{~m})$ consisted of four rose shrubs (grey triangles). One of the four tree species was randomly attributed separately to each shrub. Four saplings (dots) were planted near the shrub (i.e. position "in") and four saplings were planted at $1.5 \mathrm{~m}$ from the shrub (i.e. position "out"). obtained from a local nursery (Lobsigen, region of Bern, Switzerland). Prior to plantation of saplings in the field, heights and diameters at $1 \mathrm{~cm}$ above the root collar were measured (Table 1).

\section{Measurements}

After each of the four grazing periods in 2004 and in May 2005, we recorded, for each sapling, whether it was browsed and whether it was still alive. Saplings without living stem (i.e. brown under the bark) as well as saplings pulled out by cattle were scored as dead. Browsing frequency and survival were calculated for each species in each block at position "in" and "out" of the shrub as the proportion $(0,0.25,0.50,0.75$ and 1$)$ of the four individuals browsed and still alive. All living saplings $(n=1367)$ were harvested in May 2005, before cattle arrived. Saplings were cut $1 \mathrm{~cm}$ above the root collar, oven-dried and weighed. The impact of browsing and nurse shrubs on the growth of surviving saplings was assessed by analysing sapling biomass change (BC) by final harvest. BC was calculated as (aboveground dry mass at harvest $) \times$ (predicted aboveground dry mass at planting $)^{-1}$. BC was averaged for each shrub plant and for each position relative to the shrub plant $(B C>1$ represents an increase in biomass and $0<\mathrm{BC}<1$ a decrease in biomass). Aboveground dry mass at planting was estimated using regression models. These had been derived from measurements on randomly selected extra saplings $(n=40$ per species; see Table 1$)$.

\section{Statistical analyses}

We tested for the effects of species-group (coniferous versus deciduous), grazing intensity (zero, low, high) and position ("in", "out") and their interactions on final browsing frequency $(n=240)$, final survival $(n=360)$ and $\mathrm{BC}(n=336$; unbalanced design $)$ using a linear mixed-effects (LME) model with restricted maximum likelihood estimation. Site, with grazing intensity nested within site and block nested within grazing intensity, were specified as random effects. The use of LME models is more reliable than conventional ANOVA when analysing unbalanced data (Pinheiro \& Bates,

Table 1. Age, initial height $(H)$, diameter $(D)$ at $1 \mathrm{~cm}$ above root collar and estimated initial aboveground dry mass $(\mathrm{DM})$ of the transplanted saplings $(n=480$ per species)

\begin{tabular}{lllllll}
\hline Species & Age $(\mathrm{yr})$ & Height $(\mathrm{cm})$ & Diameter $(\mathrm{cm})$ & Dry mass $(\mathrm{g})$ & $\log ($ dry mass $)$ & $R^{2}$ \\
\hline Abies & 3 & $11.6 \pm 0.1$ & $0.262 \pm 0.003$ & $0.61 \pm 0.01$ & $0.5402 \times \log \left(D^{2} \times H\right)-0.1619$ \\
Picea & 2 & $12.5 \pm 0.2$ & $0.264 \pm 0.004$ & $1.04 \pm 0.3$ & $0.7283 \times \log \left(D^{2} \times H\right)+0.0271$ \\
Acer & 1 & $15.5 \pm 0.2$ & $0.292 \pm 0.003$ & $0.26 \pm 0.01$ & $0.9101 \times \log \left(D^{2} \times H\right)-0.7246$ \\
Fagus & 1 & $19.1 \pm 0.2$ & $0.332 \pm 0.004$ & $0.51 \pm 0.02$ & $0.8327 \times \log \left(D^{2} \times H\right)-0.593$ & 0.955 \\
\hline
\end{tabular}

Means $( \pm 1 \mathrm{SE})$ are given for each variable and species. Regression formulas, based on 40 extra saplings per species, were used to estimate aboveground dry mass from the height and diameter measures. For all models $R^{2}$ is given and $p<0.0001$. 
2000) and the interpretation of the results is more straightforward than those of generalized linear mixed models (GLMMs) (Venables \& Ripley, 2002). Assumptions of normality and homoscedasticity were fulfilled. The exclosure-data (zero grazing intensity) were never considered for analysis of the browsing frequency since the saplings within the exclosures were not browsed by cattle. Survival and growth measurements in both exclosures at each site were averaged over the same block numbers (resulting in five measurements for zero intensity at each site). We conducted an additional analysis (LME as described before) for survival and $\mathrm{BC}$ excluding the exclosure-data in order to test more precisely the differences between low and high grazing intensity. A posteriori contrasts were tested with Tukey HSD tests.

Furthermore, we tested the effects of browsing status (unbrowsed and browsed) and species-group on BC of individual saplings still alive at harvest under low and high grazing intensities ( $n=537$; unbalanced design) using the same analysis as described above. BC was log transformed to reduce heteroscedasticity. All data were analysed with $\mathrm{R}$, version 2.3.0. (R Development Core Team, 2006).

\section{Results}

\section{Browsing frequency}

Differences in browsing frequency between positions "in" and "out" were larger under low grazing intensity for both coniferous and deciduous species (intensity $x$ position, Table 2). Browsing frequency did not differ between species-groups, although the species-groupintensity interaction was marginally significant (Fig. 2, Table 2).

Table 2. Results of the linear mixed-effects models LME with the fixed effects of grazing intensity, species and position and their interactions for browsing frequency $(n=240$; exclosure-data not included $)$, survival $(n=360)$ and biomass change $(=\mathrm{BC} ; n=336)$

\begin{tabular}{|c|c|c|c|c|c|c|c|c|c|}
\hline \multirow[b]{2}{*}{ Species group } & \multicolumn{3}{|c|}{ Browsing } & \multicolumn{3}{|c|}{ Survival } & \multicolumn{3}{|l|}{$\mathrm{BC}$} \\
\hline & $F_{1,204}$ & 0.1 & Ns & $F_{1,306}$ & 32.2 & $* * * *$ & $F_{1,282}$ & 0.5 & ns \\
\hline Intensity & $F_{1,2}$ & 9.2 & $\mathrm{Ms}$ & $F_{2,4}$ & 38.4 & $* *$ & $F_{2,4}$ & 10.9 & \\
\hline Position & $F_{1,204}$ & 99.1 & $* * * *$ & $F_{1,306}$ & 41.5 & $* * * *$ & $F_{1,282}$ & 38.9 & $* * * *$ \\
\hline Spgroup $\times$ intensity & $F_{1,204}$ & 3.5 & $\mathrm{~ms}$ & $F_{2,306}$ & 13.9 & $* * * *$ & $F_{2,282}$ & 1.2 & ns \\
\hline Spgroup $\times$ position & $F_{1,204}$ & 1.0 & $\mathrm{~ns}$ & $F_{1,306}$ & 0.1 & $\mathrm{~ns}$ & $F_{1,282}$ & 2.3 & $\mathbf{n s}$ \\
\hline Intensity $\times$ position & $F_{1,204}$ & 16.3 & $* * *$ & $F_{2,306}$ & 20.1 & $* * * *$ & $F_{2,282}$ & 4.1 & $*$ \\
\hline Spgroup $\times$ intensity $\times$ position & $F_{1,204}$ & 0.01 & ns & $F_{2,306}$ & 2.0 & ns & $F_{2,282}$ & 2.4 & $\mathrm{~ms}$ \\
\hline
\end{tabular}

Browsing was evaluated after the last grazing period; survival and BC were measured at harvest (May 2005). The significance of bold interactions changes after removing the exclosure-data from the LME analysis (see Results).

ms: $0.05<p<0.1$; ns: non-significant result. ${ }^{*} p<0.05 ;{ }^{* * *} p<0.01 ;{ }^{* * *} p<0.001 ;{ }^{* * * *} p<0.0001$.
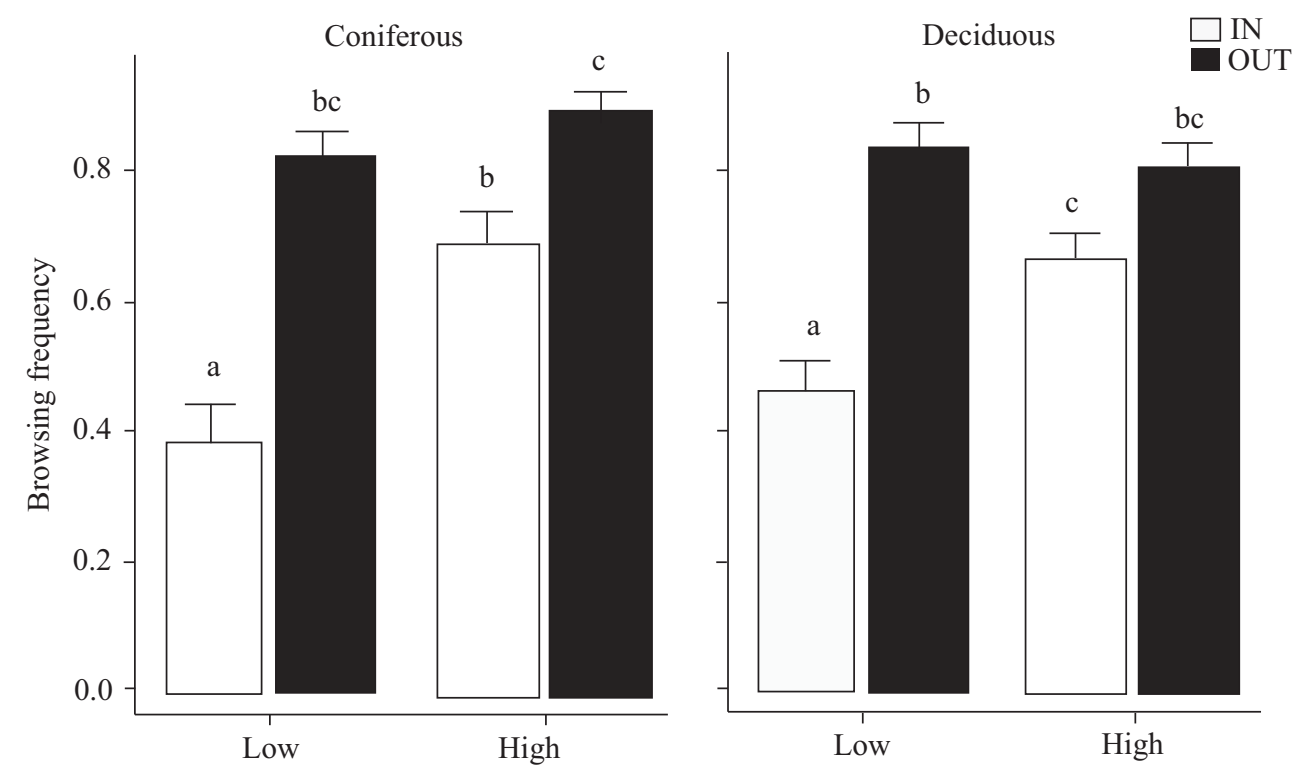

Fig. 2. The effects of grazing intensity (low and high) and position (in and out) on the browsing frequency (mean proportion \pm 1 SE, $n=30$ ) of coniferous and deciduous saplings, after the fourth grazing period. Different letters indicate significantly different means (Tukey post hoc comparisons within each species-group, $p<0.05$ ). 


\section{Survival}

Differences in survival between both shrub positions were largest under low grazing intensity (intensity $x$ position, Table 2 ), also when exclosure-data were removed from the data-set. Furthermore, differences in survival between species-groups depended on grazing intensity (species-group $\times$ intensity, Table 2): without grazing, survival was similar for both species-groups
(86-90\%), whereas with grazing, survival (mean $\pm 1 \mathrm{SE}$ ) of coniferous species $(46 \%)$ was lower than survival of deciduous species $(66 \%)$ (Fig. 3). The species-groupintensity interaction term was no longer significant $\left(F_{1}, 204=1.5, p=\mathrm{ns}\right)$ when exclosure-data were not considered in the analysis (bold in Table 2). For both species-groups, survival (mean $\pm 1 \mathrm{SE}$ ) outside shrubs was approximately equal under low and high grazing intensities, with $35 \pm 5.3 \%$ and $53 \pm 6.1 \%$ for evergreen
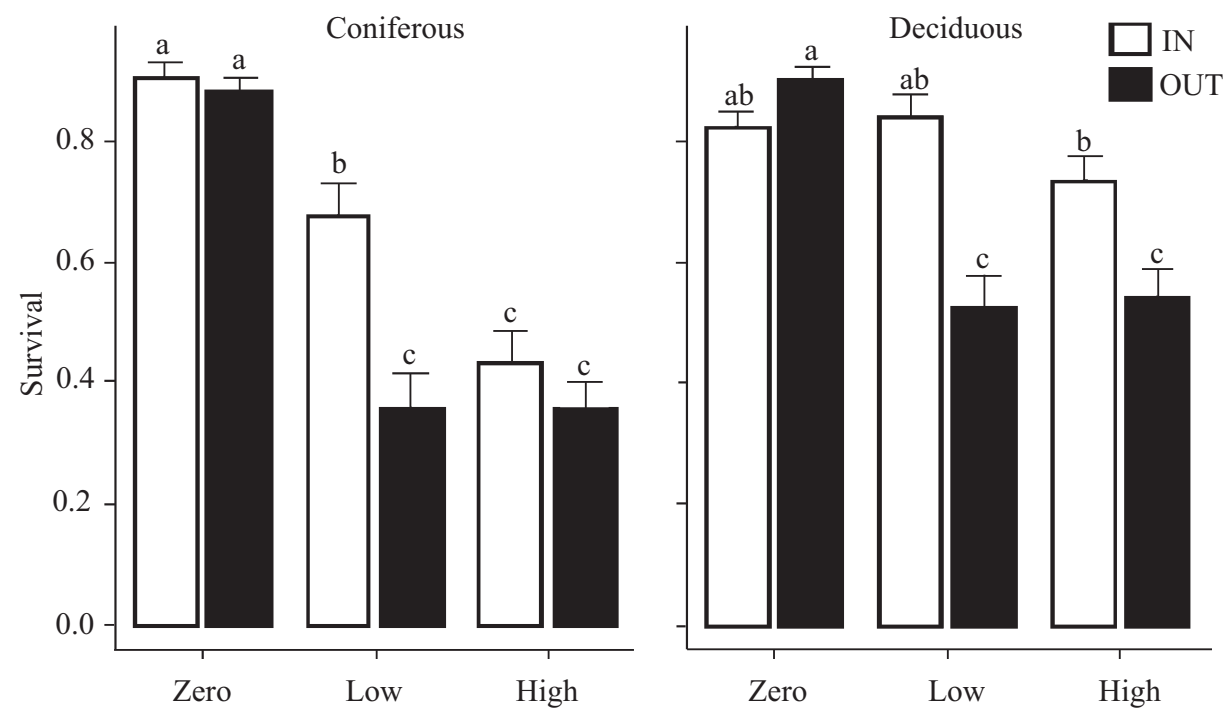

Fig. 3. The effects of grazing intensity (zero, low and high) and position (in and out) on the survival (mean proportion \pm 1 SE, $n=30$ ) of coniferous and deciduous saplings at harvest. Different letters indicate significantly different means (Tukey post hoc comparisons within each species-group, $p<0.05)$.
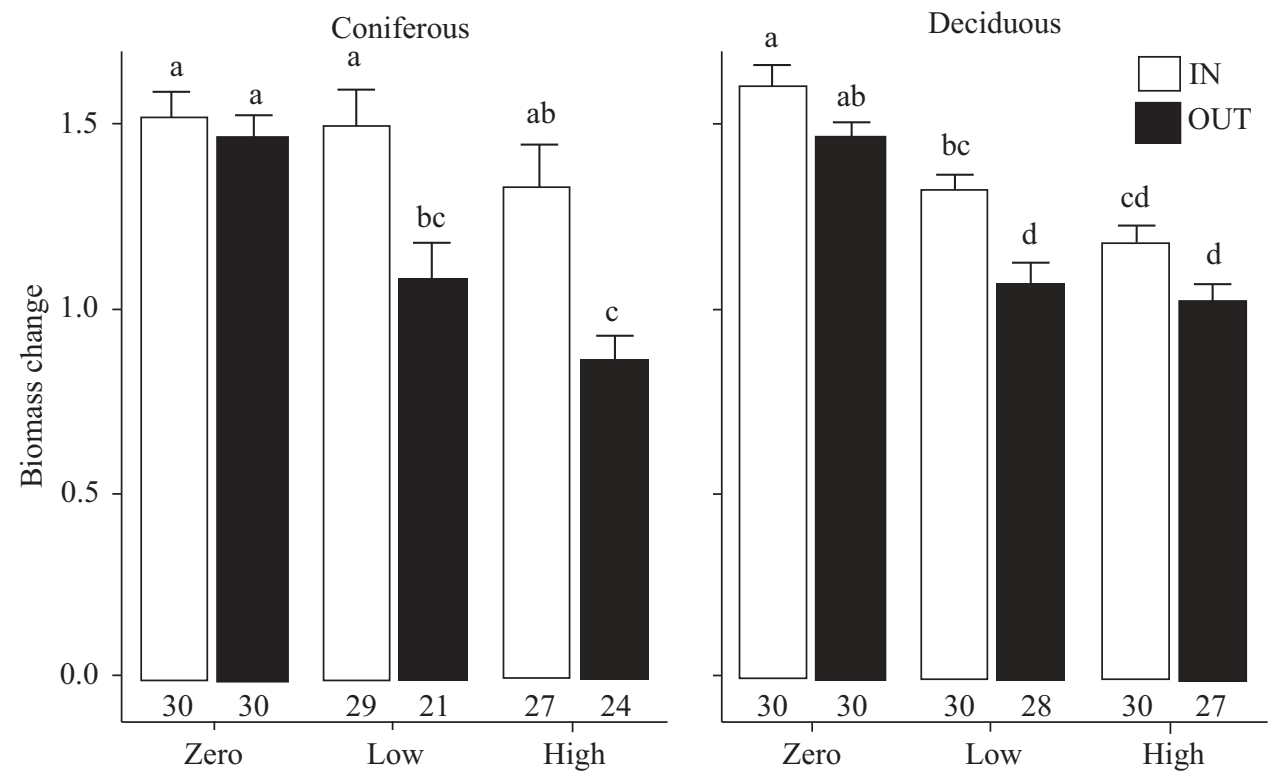

Fig. 4. The effects of grazing intensity (zero, low and high) and position (in and out) on BC of surviving coniferous and deciduous saplings at harvest (mean $\pm 1 \mathrm{SE}, n$ is given for each category). Different letters indicate significantly different means (Tukey post hoc comparisons within each species-group, $p<0.05$ ). 
and deciduous species, respectively. Only the survival of coniferous saplings beneath shrubs was significantly reduced under low intensity compared to zero intensity (Fig. 3).

\section{Biomass change of saplings alive at harvest}

Differences in BC between positions depended on grazing intensity (intensity $\times$ position, Table 2 ): differences between 'in' and 'out' were smallest under zero grazing intensity and similar under low and high grazing intensities (Fig. 4). When the exclosure-data were excluded from the analysis, the intensity $\times$ position interaction $\left(F_{1}, 180=0.1, p=\mathrm{ns}\right)$ disappeared (bold in Table 2 ). However, the species-group $\times$ position interaction became significant $\left(F_{1,180}=5.3, p<0.05\right)$ : only beneath the shrubs, BC was larger for coniferous saplings than for the deciduous ones (Fig. 4).

Differences in BC between species-groups depended on the browsing status (species-group $\times$ browsing status: $\left.F_{1,503}=30.1, p<0.0001\right)$ : coniferous saplings suffered from larger growth losses after cattle browsing (Fig. 5). Growth reduction due to browsing of the surviving saplings $\left[1-\left(\mathrm{BC} \_\right.\right.$browsed saplings $\times\left(\mathrm{BC}_{-}\right.$unbrowsed

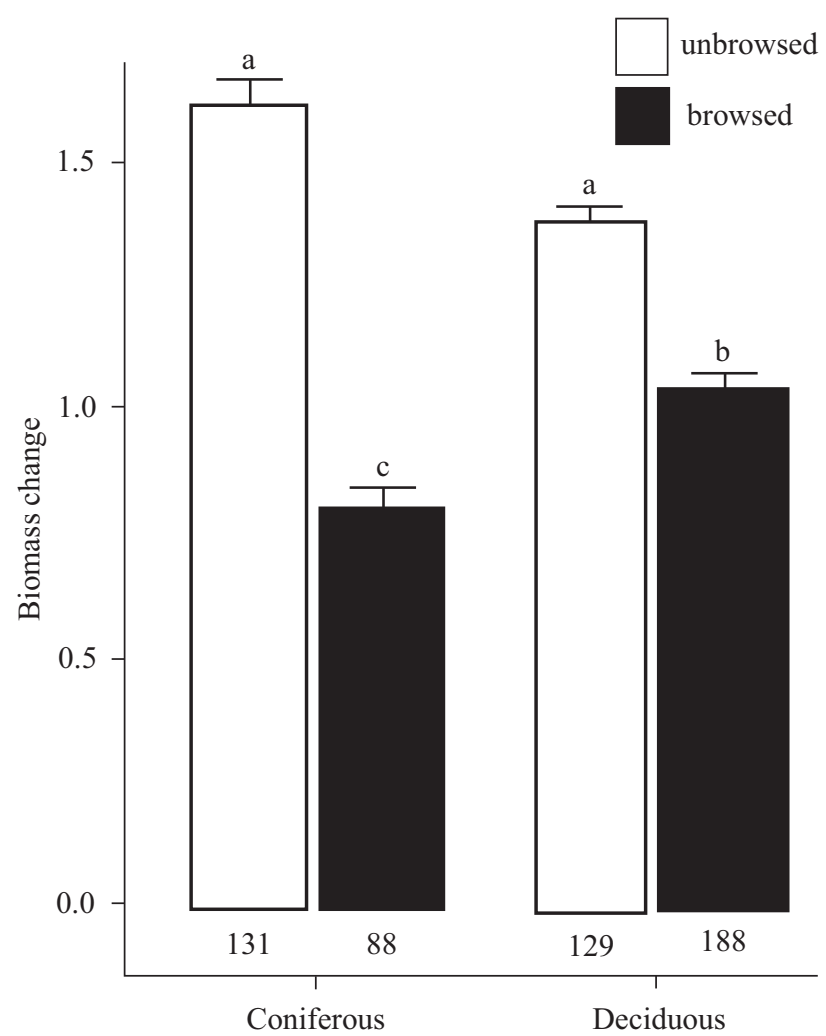

Fig. 5. The effects of species-group and browsing status on $\mathrm{BC}$ (mean $\pm 1 \mathrm{SE}, n$ is given for each category, exclosure-data are not considered) of tree saplings still alive at harvest. Different letters indicate significantly different means (Tukey post hoc comparisons, $p<0.05)$. saplings $)^{-1}$ )] was $51 \%$ for coniferous and $27 \%$ for deciduous species. $40 \%$ of the coniferous and $59 \%$ of the deciduous saplings still alive at harvest was browsed.

\section{Discussion}

\section{Coniferous and deciduous sapling responses to facilitation}

As expected, the saplings of the coniferous Abies and Picea were less resistant (i.e. higher mortality and biomass loss) to cattle browsing than the Acer and Fagus saplings. Since browsing frequency did not differ between species, avoidance could not have been the main mechanism explaining this difference. The lower survival of the coniferous species was presumably, as found previously by Vandenberghe et al. (2007), due to a greater biomass off-take as a consequence of more vulnerable plant architecture (i.e. dense, large horizontal evergreen branches and canopy close to the herbaceous field layer versus less dense, erect branches) rather than higher compensation abilities of deciduous species (Chapin, Schulze, \& Mooney, 1990; Hester, Millard, Baillie, \& Wendler, 2004). Moreover, the compensatory growth responses of deciduous species did not differ from that of the coniferous species in a simulating browsing experiment using saplings of the same species and size (Vandenberghe, Freléchoux, \& Buttler, 2008). Although deciduous species were initially on average $5 \mathrm{~cm}$ taller, and thus a priori more apparent, cattle affected browsing frequency and survival of coniferous species more rapidly than deciduous species (data not shown). The abundant and attractive fresh foliage of the coniferous species early in the season (Welch, Staines, Scott, French, \& Catt, 1991) might therefore explain their lower resistance.

Shrubs indirectly facilitated the saplings by protecting them from cattle. For both species-groups, facilitation in terms of sapling browsing frequency and sapling survival was strongest at low levels of grazing intensity. The reduction in facilitation under high grazing intensities was related to increased damage of the nurse plants (Smit et al., 2007), allowing for incidental browsing of saplings under the shrubs, and it was most likely a consequence of decreased potential for selectivity by grazers (Crawley, 1983). Increased browsing on nurse shrubs will not always lead to a hump-backed response as for some nurse species it may also result in increased spinescence or a different structure leading to better protection for associated tree saplings (García \& Obeso, 2003). In contrast with the reduced facilitation at high grazing intensity in terms of browsing frequency and sapling survival, facilitation in terms of sapling growth was not reduced at high grazing intensity. This 
was due to the fact that surviving saplings did not differ in growth between the low and high grazing intensities in both positions.

We expected that the less resistant coniferous saplings would benefit more from nurse shrubs than would the more resistant deciduous species. Evidence for this hypothesis was found for growth of the surviving saplings, but not for browsing frequency or survival. The surviving coniferous saplings were less browsed $(20 \%)$ than the deciduous saplings, which resulted in lower overall growth loss beneath shrubs. The surprising lack of species-group response to facilitation in terms of survival is due to the fact that the less resistant coniferous species had an overall lower survival than the deciduous species, both outside and beneath nurse shrubs. These lower survival rates beneath shrubs were not related to differences in browsing frequency but rather to a greater biomass off-take (see above, Fig. 5). Moreover, facilitation of survival under high grazing intensity tended to become weaker for coniferous species than for deciduous species. Consequently, the expected increase in facilitation strength of coniferous species will most probably be reached at grazing intensities lower than the one used in this study. In other words, if shrubs would act as a perfect barrier against cattle browsing (i.e. browsing frequency equals zero), species-group responses to facilitation could become significant.

No significant facilitative or competitive interactions under zero grazing intensity were found. Other studies demonstrate how tree species react differently to modified environmental conditions (e.g. shade, competition from neighbours, nutrients, water, etc.) caused by nurse plants (Dolezal, St'astna, Hara, \& Srutek, 2004; Gómez-Aparicio et al., 2005; Gómez-Aparicio, Zamora, Castro, \& Hódar, 2008). Such interactions were demonstrated in more severe ecosystems (i.e. drier and warmer) than our high-productive study area. Pagès and Michalet (2003) found that the indirect positive effect of competition release for tree saplings by adult trees in a temperate hardwood forest was outweighed by the direct negative effect of light reduction. We suggest that microsites and resources (e.g. nutrients, light) inside and outside shrubs did not differ sufficiently to provoke large facilitative or competitive interactions. Thus, protection against grazing was the main indirect facilitation mechanism. Our study was based on sapling heights initially ranging between 10 and $20 \mathrm{~cm}$, while other sizes of the target species might change the net outcome of the biotic interactions (Olff et al., 1999). Associational effects will also vary strongly among systems as they depend on the selectivity of the herbivores, heterogeneity and productivity of the grazed patches, and palatability of nurse plants and protégés (Baraza, Zamora, \& Hódar, 2006; García \& Obeso, 2003; Gómez, Hódar, Zamora, Castro, \& Garcia, 2001; Gómez-Aparicio et al., 2008).
In conclusion, we found that the less resistant surviving coniferous saplings did benefit more from facilitation in terms of growth than the more resistant deciduous saplings, which is in agreement with our hypothesis. In contrast, the coniferous saplings did not benefit more from facilitation in terms of overall survival due to incidental browsing by herbivores on the nurse plants and protégé sapling browsing underneath (Gómez et al., 2001; Smit et al., 2007). At high grazing intensities, coniferous saplings tended to benefit even less from facilitation.

\section{Implications for wood-pasture systems}

Most of the ancient wood-pastures suffered a dramatic decline during the last century due to changes in agricultural practices (Etienne, 1996; Manning et al., 2006). If management deviates from a balance between intensification and extensification, wood-pastures evolve towards either open pastures or closed forests with concomitant loss of biodiversity (Gillet, 2005). Periods where grazing is excluded to allow for regeneration of the tree resource or where grazing is intensified to limit natural reforestation, could only be a short-term management solution before reinstating seasonal or year-round grazing. A more sustainable and natural solution may be applying facilitation of tree recruitment via nurse plants, particularly as extensive grazing is an integral part of long-term management of woodpastures. This study shows that the strength of facilitation decreases with increasing grazing intensity and in particular for the less resistant conifers. Within the context of conservation and restoration of woodpastures, this means that grazing intensity needs to be kept low to promote the effectiveness of facilitation for all tree species.

\section{Acknowledgements}

We thank Agroscope Changins-Wädenswil (ACW), in particular J. Troxler, for providing the site, material and information about La Petite Ronde. We thank S. Attinger, C. Rosat, L. Freléchoux, M. Köppen and T. Ekamper for field assistance, and M. Burkhard for providing geological data. We thank R. Brooker and N. Littlewood for improving this manuscript with useful comments. We acknowledge the support of the National Centre of Competence in Research (NCCR). This study was financially supported by MAVA and the Swiss Federal Research Institute WSL (program Walddynamik).

\section{References}

Bakker, E. S., Olff, H., Vandenberghe, C., De Maeyer, K., Smit, R., Gleichman, J. M., et al. (2004). Ecological 
anachronisms in the recruitment of temperate lightdemanding tree species in wooded pastures. Journal of Applied Ecology, 41, 571-582.

Baraza, E., Zamora, R., \& Hódar, J. A. (2006). Conditional outcomes in plant-herbivore interactions: Neighbours matter. Oikos, 113, 148-156.

Bertness, M. D., \& Callaway, R. (1994). Positive interactions in communities. Trends in Ecology and Evolution, 9, 191-193.

Boege, K., \& Marquis, R. J. (2005). Facing herbivory as you grow up: The ontogeny of resistance in plants. Trends in Ecology and Evolution, 20, 441-448.

Brooker, R. W., \& Callaghan, T. V. (1998). The balance between positive and negative plant interactions and its relationship to environmental gradients: A model. Oikos, 81, 196-207.

Brooker, R. W., Scott, D., Palmer, S. C. F., \& Swaine, E. (2006). Transient facilitative effects of heather on Scots pine along a grazing disturbance gradient in Scottish moorland. Journal of Ecology, 94, 637-645.

Brooker, R. W., Maestre, F. T., Callaway, R. M., Lortie, C. L., Cavieres, L. A., Kunstler, G., et al. (2008). Facilitation in plant communities: The past, the present and the future. Journal of Ecology, 96, 18-34.

Bruno, J. F., Stachowicz, J. J., \& Bertness, M. D. (2003). Inclusion of facilitation into ecological theory. Trends in Ecology and Evolution, 18, 119-125.

Callaway, R. M., Brooker, R. W., Choler, P., Kikvidze, Z., Lortie, C. J., Michalet, R., et al. (2002). Positive interactions among alpine plants increase with stress. Nature, 417 , 844-848.

Callaway, R. M., Kikodze, D., Chiboshvili, M., \& Khetsuriani, L. (2005). Unpalatable plants protect neighbors from grazing and increase plant community diversity. Ecology, 86, 1856-1862.

Chapin, F. S., Schulze, E. D., \& Mooney, H. A. (1990). The ecology and economics of storage in plants. Annual Review of Ecology and Systematics, 21, 423-447.

Cheng, D. L., Wang, G. X., Chen, B. M., \& Wei, X. P. (2006). Positive interactions: Crucial organizers in a plant community. Journal of Integrative Plant Biology, 48, 128-136.

Choler, P., Michalet, R., \& Callaway, R. M. (2001). Facilitation and competition on gradients in alpine plant communities. Ecology, 82, 3295-3308.

Crawley, M. J. (1983). Herbivory. Studies in ecology, vol 10: The dynamics of animal-plant interactions. Oxford: Blackwell.

Dolezal, J., St'astna, P., Hara, T., \& Srutek, M. (2004). Neighbourhood interactions and environmental factors influencing old-pasture succession in the Central Pyrenees. Journal of Vegetation Science, 15, 101-108.

Etienne, M. (1996). Research on temperate and tropical silvopastural systems: A review. In M. Etienne (Ed.), Western European silvopastural systems (pp. 5-19). Paris: INRA.

García, D., \& Obeso, J. R. (2003). Facilitation by herbivoremediated nurse plants in a threatened tree, Taxus baccata: Local effects and landscape level consistency. Ecography, 26, 739-750.
Gillet, F. (2005). Modelling vegetation dynamics in heterogeneous pasture-woodland landscapes. In Komarov, A. S. (Ed.), Proceedings of ECEM 2005, fifth European conference on ecological modelling (pp. 60-61). Pushchino, Russia.

Gómez, J. M., Hódar, J. A., Zamora, R., Castro, J., \& Garcia, D. (2001). Ungulate damage on Scots pines in Mediterranean environments: Effects of association with shrubs. Canadian Journal of Botany, 79, 739-746.

Gómez-Aparicio, L., Valladares, F., Zamora, R., \& Quero, J. L. (2005). Response of tree seedlings to the abiotic heterogeneity generated by nurse shrubs: An experimental approach at different scales. Ecography, 28, 757-768.

Gómez-Aparicio, L., Zamora, R., Castro, J., \& Hódar, J. A. (2008). Facilitation of tree saplings by nurse shrubs: Microhabitat amelioration or protection against herbivores? Journal of Vegetation Science, 19, 161-172.

Grime, J. P. (1977). Evidence for existence of 3 primary strategies in plants and its relevance to ecological and evolutionary theory. American Naturalist, 111, 1169-1194.

Hester, A. J., Bergman, M., Iason, G., \& Moen, J. (2006). Impacts of large herbivores on plant community structure and dynamics. In K. Danell, R. Bergström, P. Duncan, \& J. Pastor (Eds.), Large herbivore ecology, ecosystem dynamics and conservation (pp. 97-141). Cambridge: Cambridge University Press.

Hester, A. J., Millard, P., Baillie, G. J., \& Wendler, R. (2004). How does timing of browsing affect above- and belowground growth of Betula pendula, Pinus sylvestris and Sorbus aucuparia? Oikos, 105, 536-550.

Hester, A. J., Mitchell, F. J. G., \& Kirby, K. J. (1996). Effects of season and intensity of sheep grazing on tree regeneration in a British upland woodland. Forest Ecology and Management, 88, 99-106.

Kirby, K., Thomas, R., Key, R., McLean, I., \& Hodgetts, N. (1995). Pasture-woodland and its conservation in Britain. Biological Journal of the Linnean Society, 56(Suppl.), 135-153.

Lehmkuhler, J. W., Felton, E. E. D., Schmidt, D. A., Bader, K. J., Garrett, H. E., \& Kerley, M. S. (2003). Tree protection methods during the silvopastoral-system establishment in midwestern USA: Cattle performance and tree damage. Agroforestry Systems, 59, 35-42.

Liancourt, P., Callaway, R. M., \& Michalet, R. (2005). Stress tolerance and competitive-response ability determine the outcome of biotic interactions. Ecology, 86, 1611-1618.

Maestre, F. T., Valladares, F., \& Reynolds, J. F. (2006). The stress-gradient hypothesis does not fit all relationships between plant-plant interactions and abiotic stress: Further insights from arid environments. Journal of Ecology, 94, $17-22$.

Manning, A. D., Fischer, J., \& Lindenmayer, D. B. (2006). Scattered trees are keystone structures - implications for conservation. Biological Conservation, 132, 311-321.

Michalet, R., Brooker, R. W., Cavieres, L. A., Kikvidze, Z., Lortie, C. J., Pugnaire, F. I., et al. (2006). Do biotic interactions shape both sides of the humped-back model of species richness in plant communities? Ecology Letters, 9, 767-773. 
Mühlethaler, C. (1930). La Chaux, Les Verrières. Atlas géologique de la Suisse. Commission Géologique de la Société Helvétique des Sciences Naturelles. Carte et notice explicative.

Olff, H., Vera, F. W. M., Bokdam, J., Bakker, E. S., Gleichman, J. M., De Maeyer, K., et al. (1999). Shifting mosaics in grazed woodlands driven by the alternation of plant facilitation and competition. Plant Biology, 1, 127-137.

Pagès, J. P., \& Michalet, R. (2003). A test of the indirect facilitation model in a temperate hardwood forest of the Northern French Alps. Journal of Ecology, 91, 932-940.

Pinheiro, J. C., \& Bates, D. M. (2000). Mixed-effects models in $S$ and S-plus. New York: Springer.

Pott, R., \& Hüppe, J. (1991). Die Hudelandschaften Nordwestdeutschlands. Landschaftsverband Westfalen-Lippe, Veröfftentlichung der Arbeitsgemeinschaft für biologischökologische Landeserforschung, ABÖL, no. 89, Westfälisches Museum für Naturkunde, Münster.

$\mathrm{R}$ Development Core Team. (2006). $R$ : A language and environment for statistical computing. $\mathrm{R}$ Foundation for statistical computing, Version 2.3.0, Vienna, Austria $\langle$ http://www.R-project.org/ $\rangle$.

Rosenthal, J. P., \& Kotanen, P. M. (1994). Terrestrial plant tolerance to herbivory. Trends in Ecology and Evolution, 9, $145-148$.

Smit, C., Béguin, D., Buttler, A., \& Müller-Schärer, H. (2005). Safe sites for tree regeneration in wooded pastures: A case of associational resistance? Journal of Vegetation Science, 16, 209-214.

Smit, C., den Ouden, J., \& Müller-Schärer, H. (2006). Unpalatable plants facilitate tree sapling survival in wooded pastures. Journal of Applied Ecology, 43, 305-312.
Smit, C., Vandenberghe, C., den Ouden, J., \& Müller-Schärer, H. (2007). Nurse plants, tree saplings and grazing pressure: Changing facilitation along a biotic environmental gradient. Oecologia, 152, 265-273.

Tirado, R., \& Pugnaire, F. I. (2005). Community structure and positive interactions in constraining environments. Oikos, 111, 437-444.

Travis, J. M. J., Brooker, R. W., Clark, E. J., \& Dytham, C. (2006). The distribution of positive and negative species interactions across environmental gradients on a dual-lattice model. Journal of Theoretical Biology, 241, 896-902.

Vandenberghe, C., Freléchoux, F., \& Buttler, A. (2008). The influence of competition from herbaceous vegetation and shade on simulated browsing tolerance of coniferous and deciduous saplings. Oikos, 117, 415-423.

Vandenberghe, C., Freléchoux, F., Moravie, M.-A., Gadallah, F., \& Buttler, A. (2007). Short-term effects of cattle grazing on tree sapling growth in mountain wooded pastures. Plant Ecology, 188, 253-264.

Venables, W. N., \& Ripley, B. D. (2002). Modern applied statistics with $S$ (4th ed.). New York: Springer.

Vera, F. W. M., Bakker, E. S., \& Olff, H. (2006). Large herbivores: Missing partners of western European lightdemanding tree and shrub species. In K. Danell, R. Bergström, P. Duncan, \& J. Pastor (Eds.), Large herbivore ecology, ecosystem dynamics and conservation (pp. 203-222). Cambridge: Cambridge University Press.

Welch, D., Staines, B. W., Scott, D., French, D. D., \& Catt, D. C. (1991). Leader browsing by red and roe deer on young Sitka spruce trees in western Scotland 1. Damage rates and the influence of habitat factors. Forestry, 64, 61-82. 